\title{
On-farm welfare assessment in dairy goats in the Brazilian Northeast
}

[Avaliação do bem-estar de cabras leiteiras em fazendas no nordeste brasileiro]

\author{
L.O. Leite ${ }^{1}$, F.O. Stamm ${ }^{2}$, R.A. Souza ${ }^{3}$, J.A. Camarinha Filho ${ }^{3}$, R.C.M. Garcia ${ }^{3}$ \\ ${ }^{1}$ Aluna de pós-graduação - Universidade Estadual do Ceará - Fortaleza, CE \\ ${ }^{2}$ Zootecnista - Universidade Federal do Paraná - Curitiba, PR \\ ${ }^{3}$ Estatístico - Universidade Federal do Paraná - Curitiba, PR \\ ${ }^{4}$ Universidade Federal do Paraná - Curitiba, PR
}

\begin{abstract}
The objective of this study was to apply a modified AWIN Goat protocol to evaluate and compare the welfare of adult lactating and non-lactating dairy goats at pen and individual levels on small farms located in Ceará, Northeast, Brazil, and to take into consideration the application of this protocol on Brazilian Northeast goat farms. Five farms with Lactating goats (L) and five farms with non-lactating goats (NL) were evaluated. At the first level of welfare assessment, animals were evaluated in the pen and during the second level of welfare assessment, animals were evaluated in the pen and individually. Indicators assessed were animal and resourcebased indicators. Significant difference between $\mathrm{L}$ and NL on farms was set at $\mathrm{P}<0.05$. Only queuing at feeding indicator showed significant difference $(\mathrm{P}=0.027)$ between groups in pens at the first level welfare assessment. On individual assessments, there was significant difference between $\mathrm{L}$ and NL regarding body condition score $(\mathrm{P}=0.003)$, overgrown claws $(\mathrm{P}=0.001)$ and udder asymmetry $(\mathrm{P}=0.001)$. The application of a modified AWIN Goat protocol on farms in Ceará was considered positive. In general, these results demonstrated that both groups are submitted to welfare problems in Ceará, although lactating goats present more challenges to cope.
\end{abstract}

Keywords: goat welfare, animal production, AWIN protocol, animal-based indicator, resource-based indicator

\section{RESUMO}

O objetivo deste estudo foi aplicar o protocolo AWIN de Cabras modificado para avaliar e comparar o bem-estar de cabras adultas lactantes e não lactantes em termos de baia e individualmente, em pequenas propriedades localizadas no Ceará, nordeste, Brasil, e levar em consideração a aplicação desse protocolo em fazendas caprinas do nordeste brasileiro. Cinco fazendas com cabras lactantes $(L)$ e cinco fazendas com cabras não lactantes (NL) foram avaliadas. No primeiro nível de bem-estar, os animais foram avaliados nas baias e, durante o segundo nível de bem-estar, os animais foram avaliados na baia $e$ individualmente. Os indicadores avaliados foram baseados em animais e recursos. Diferença significativa entre $L$ e NL nas fazendas foi estabelecida em $P<0,05$. Apenas o indicador na fila na alimentação mostrou diferença significativa $(P=0,027)$ entre os grupos na baia no primeiro nível de bem-estar. Nas avaliações individuais, houve diferença significativa entre $L$ e $N L$ com relação ao escore de condição corporal $(P=0,003)$, sobrecrescimento das unhas $(P=0,001)$ e assimetria do úbere $(P=0,001)$. A aplicação do protocolo AWIN de cabras modificado em fazendas no Ceará foi considerada positiva. De modo geral, esses resultados demonstraram que ambos os grupos estão submetidos a problemas de bem-estar no Ceará, embora cabras em lactação apresentem mais desafios para enfrentar.

Palavras-chave: bem-estar de cabras, produção animal, protocolo AWIN, indicador baseado em animal, indicador baseado em recurso

\section{INTRODUCTION}

Goats are considered rustic animals because of their ability to cope with harsh environments and bad management practices and consequently people used to think that welfare problems and low productive performance are not related to these challenges (Sevi et al., 2009). This thought has been changing in recent decades and concerns about animal welfare has been increasing. Conscious consumers are claiming for safe products that respect animals over all the process,

Recebido em 11 de setembro de 2019

Aceito em 25 de junho de 2020

E-mail: luanaoliv.vet@gmail.com 
and this is a reality in Brazil and also in the Northeast (Queiroz et al., 2014).

Dairy goat farming has been an important activity for the income support of small producers, especially in the Brazilian Northeast (Ferreira et al., 2016). Assessing the welfare of these animals is a new and complementary method to improve the quality of goat's milk, especially in this region, which holds the largest herd of goats in Brazil (93.0\%), with Ceará state being the fourth that raises the most goats (11.6\%) (PPM, 2016). Goats' welfare can be assessed through AWIN Goat, a protocol developed to evaluate dairy goats welfare, mainly animals kept under semiintensive and intensive production systems (Mattiello et al., 2015). This protocol uses animalbased indicators, related to natural behavior of species, physical and mental health; resource and management based parameters, including stocking density and health plans.

The protocol was designed to evaluate the welfare of lactating adult dairy goats, but the selected indicators were chosen based on goat's biology, which allows them to be tested in other categories, such as non-lactating females. Lactating mammals have high physiological demands (Speakman, 2008) and depending on the milking conditions, goats can suffer emotional and physical stress resulting in decreased productivity and health problems (Sevi et al., 2009). The use of the protocol on non-lactating goats is justified because semiarid and arid regions, as is the case of Brazilian Northeast, are characterized by a strong rainfall seasonality, leading to water restriction and, consequently, to reproductive problems on some goat flocks (Salem, 2010). Therefore, some farms in this region have problems in having lactating goats, but it is important that these animals also have their welfare monitored.

Although non-lactating females are under less physiological pressure, several factors can also affect the welfare of these animals: the quality of the relationship with the handlers, demonstrated in the way the goat kids are handled until became adults; health care, which is important in all stages of the animal's life to ensure an adequate growth with good conditions of body score and coat; the management of the herd that is affected by the purchase and sale of animals, generating exchanges and reallocations of goats in different groups, which promotes stress and aggression among animals, and the construction of inadequate facilities that promote overcrowding which also generates behavioral changes (Caroprese et al., 2009). It is possible that other factors, such as those related to the design of housing systems and the type of management, affect the welfare degree of these animals (Broom, 1986).

There are several researches involving goat's welfare and behavior (Lickliter, 1985; Briefer et al., 2015, Grosso et al., 2016; Mersmann et al., 2016), but few studies published in Brazil related to this subject (Lima and Barbosa Filho, 2013; Paulo and Lopes, 2014; Baxter et al., 2016). In order to better understand dairy goats' welfare, the objective of this study was to apply a modified AWIN Goat protocol to evaluate and compare the welfare of adult lactating and non-lactating dairy goats in pens and individual level on small farms located in Ceará, Northeast, Brazil. In addition, considerations about the use of AWIN Goat on dairy farms in Ceará, Northeast, Brazil, were commented.

\section{MATERIAL AND METHODS}

Ten small farms located in Ceará were used in this study, five with lactating goats (L; Farms 1 to 5) and five with non-lactating goats (NL; Farms 1 to 5). L farms were located in the metropolitan Region of Fortaleza $(n=3)$ and East Coast Jaguaribe $(n=2)$. NL farms were located in the metropolitan Region of Fortaleza $(n=3)$ and Central Sertão $(n=2)$. One farm (Farm 5) was used to evaluate both groups lactating goats and nonlactating goats. In order to evaluate animal and resource-based indicators, a modified AWIN Goat protocol (Dwyer et al., 2015; Mattiello et al., 2015) was applied in a two-level approach (Table 1). At the first welfare level, the evaluations occurred at pen level, without any physical contact with goats. The chosen pen should be the one with the highest risk of poor animal welfare.

Ten animal-based indicators were assessed (Table 2): improper disbudding, abscess, kneeling at the feed rack, queuing at feeding, queuing at drinking, hair coat condition, oblivion, thermal stress, latency to the first contact test (LFCT) and severe lameness. Queuing at feeding and at drinking were recorded as the number of time that the behavior occurred and not the number of goats that performed it. The authors used this approach 
in order to better understand the intensity of this behavior in each group. Qualitative behavior assessment data were not used in this study because the low number of evaluated farms are not enough to provide reliable statistical results. Ten resource-based indicators were also evaluated (Table 3).

Table 1. Characterization of farms assessed in Ceará, Brazil

\begin{tabular}{|c|c|c|c|c|c|c|c|c|}
\hline 㯊 & 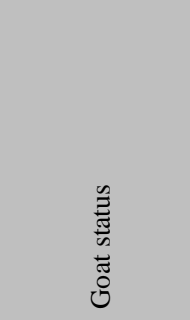 & 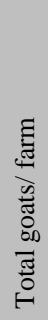 & 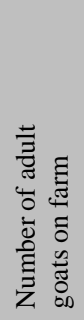 & 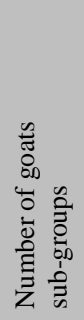 & 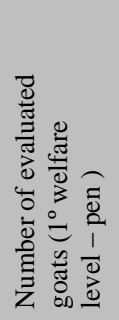 & 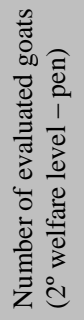 & 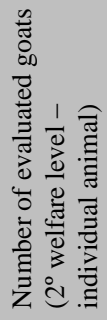 & 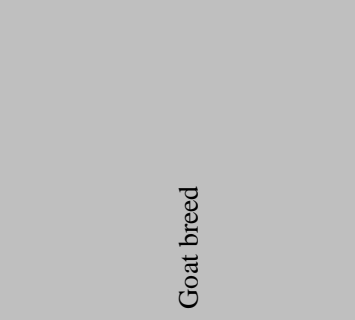 \\
\hline Farm 1 & Lactating & 30 & 6 & 1 & 6 & 0 & 6 & Saanen \\
\hline Farm 2 & Lactating & 50 & 20 & 4 & 4 & 3 & 16 & Saanen/British alpine \\
\hline Farm 3 & Lactating & 30 & 9 & 1 & 9 & 0 & 9 & $\begin{array}{l}\text { Saanen/Alpine/Mixed breed of } \\
\text { Saanen and Alpine }\end{array}$ \\
\hline Farm 4 & Lactating & 18 & 18 & 1 & 18 & 0 & 18 & Saanen \\
\hline Farm 5 & Lactating & 56 & 22 & 5 & 8 & 8 & 21 & Saanen \\
\hline Farm 1 & Non- Lactating & 5 & 5 & 3 & 2 & 2 & 5 & Saanen \\
\hline Farm 2 & Non- Lactating & 6 & 6 & 2 & 3 & 3 & 6 & Murciana/Canindé \\
\hline Farm 3 & Non- Lactating & 20 & 8 & 2 & 5 & 3 & 8 & $\begin{array}{l}\text { Saanen/Alpine/Mixed breed of } \\
\text { Saanen and Alpine }\end{array}$ \\
\hline Farm 4 & Non- Lactating & 9 & 6 & 1 & 6 & 0 & 6 & $\begin{array}{l}\text { Mixed breed of Saanen and } \\
\text { Alpine }\end{array}$ \\
\hline Farm 5 & Non- Lactating & 56 & 34 & 5 & 14 & 0 & 23 & Saanen \\
\hline
\end{tabular}

Table 2. Description of animal-based indicators applied at first level welfare assessment on farms in Ceará, Brazil

\begin{tabular}{|c|c|}
\hline Indicator & Description \\
\hline Improper disbudding & The number of goats showing presence of residual horns (scurs) is recorded. \\
\hline Abscess & The presence of external abscesses in front area is recorded. \\
\hline $\begin{array}{l}\text { Kneeling at the feed } \\
\text { rack }\end{array}$ & $\begin{array}{l}\text { The number of kneeling goats (front legs flexed, the rear up compared to other } \\
\text { goats) is counted during feeding time. }\end{array}$ \\
\hline Queuing at feeding & $\begin{array}{l}\text { The number of goats queuing at the feed rack, during feeding time, is counted } \\
\text { using a scan sampling method until } 15 \text { minutes. }\end{array}$ \\
\hline Queuing at drinking & $\begin{array}{l}\text { The number of goats queuing at the drinkers, during or after feeding time, is } \\
\text { counted using a scan sampling method until } 15 \text { minutes. }\end{array}$ \\
\hline Hair coat condition & $\begin{array}{l}\text { The number of goats presenting poor hair coat (defined as matted, rough, } \\
\text { scurfy, uneven, shaggy hair coat frequently longer than normal) is recorded. }\end{array}$ \\
\hline Oblivion & $\begin{array}{l}\text { The number of oblivious goats (physically or mentally isolated from the } \\
\text { group) is recorded. }\end{array}$ \\
\hline Thermal stress & $\begin{array}{l}\text { Number of goats showing heat (high accelerate respiration rate) or cold } \\
\text { (shivering or presence of bristly hair) stress signs is counted. }\end{array}$ \\
\hline $\begin{array}{l}\text { Latency to the first } \\
\text { contact test (LFCT) }\end{array}$ & $\begin{array}{l}\text { The latency from the time the first goat nuzzles or touches any part of the } \\
\text { assessor's body that was immobile in a selected place in the pen is recorded } \\
\text { (maximum time: } 300 \text { seconds). }\end{array}$ \\
\hline Severe Lameness & $\begin{array}{l}\text { Goats are moved in the pen and the number of severely lame animals (based } \\
\text { on abnormal gait, head nodding, spine curvature, and presence of kneeling in } \\
\text { different places than the feeding rack) is counted. }\end{array}$ \\
\hline
\end{tabular}

Table was adapted from Battini et al. (2015a). 
Table 3. Description of resource-based indicators applied in the assessments of farms in Ceará, Brazil

\begin{tabular}{|c|c|}
\hline Indicator & Description \\
\hline${ }^{a}$ Stocking density & $\begin{array}{l}\text { The individual space }(\mathrm{m}) \text { of each goat was calculated based on the total } \\
\text { area }\left(\mathrm{m}^{2}\right) \text { of the pen and divided by the number of goats. }\end{array}$ \\
\hline${ }^{\mathrm{b}}$ Number of feeding spaces & The number of feeding spaces is recorded. \\
\hline $\begin{array}{l}\mathrm{b} \text { The length }(\mathrm{m}) \text { of feeding } \\
\text { trough }(\mathrm{s}) \text { per goat }\end{array}$ & $\begin{array}{l}\text { The individual length of feeding trough }(\mathrm{s}) \text { that each goat has to feed is } \\
\text { recorded. }\end{array}$ \\
\hline $\begin{array}{l}{ }^{\mathrm{b}} \text { Number of functioning } \\
\text { water places }\end{array}$ & Number of functioning water places is recorded. \\
\hline $\begin{array}{l}{ }^{\mathrm{b}} \text { Presence of linear } \\
\operatorname{trough}(\mathrm{s})(\mathrm{m})\end{array}$ & The presence of linear trough $(\mathrm{s})(\mathrm{m})$ is recorded. \\
\hline $\begin{array}{l}{ }^{\mathrm{b}} \text { Total length }(\mathrm{m}) \text { of linear } \\
\text { water trough }(\mathrm{s}) \text { per goat }\end{array}$ & $\begin{array}{l}\text { The individual length of linear water trough(s) that each goat has to drink } \\
\text { is recorded. }\end{array}$ \\
\hline $\begin{array}{l}{ }^{\mathrm{b}} \text { Presence of horned and } \\
\text { dehorned goats }\end{array}$ & The Presence of horned and dehorned goats at the same pen is recorded. \\
\hline${ }^{\mathrm{b}}$ Flooring material & The type of flooring material on each pen is recorded. \\
\hline${ }^{\mathrm{b}}$ Bedding material & The type of bedding material on each pen is recorded. \\
\hline
\end{tabular}

As for the indicators "quantity of bedding and quality of bedding", the authors replaced the "Not applicable (NA)" classification of these parameters, contained in AWIN Goat (Mattiello et al., 2015), for "No bedding" as a way to facilitate readers' comprehension: stocking density, number of feeding spaces, total length $(\mathrm{m})$ of feed trough(s) per goat, number of functioning water places, total length $(\mathrm{m})$ of linear water trough(s) per goat, presence of horned and dehorned goats, flooring material, bedding material, quantity and cleanness of bedding. Stocking density, an indicator used to assess sheep welfare, AWIN Sheep (Dwyer et al., 2015), was also applied because over crowdedness is a common welfare problem reported in goat groups which generates stress and aggression among animals (Caroprese et al., 2009), influencing group cohesion (Miranda-de-la Lama and Matiello, 2010). At the second welfare level, a modified AWIN Goat protocol was applied at pen and at individual level. On Farm 4 NL at the time of the visit, it was decided not to measure the area of the goat's pen due to its size $\left(>8 \mathrm{~m}^{2}\right.$ per animal).

At the second level of welfare assessment, the evaluations occurred at pen level and individual level. At pen level, resource-based indicators, except for stocking density (Dwyer et al., 2015), and animal-based indicators were applied according to AWIN Goat protocol (Mattiello et al., 2015). Abscess indicator was not applied at this level. At individual level, seven animal-based indicators were evaluated (Table 4): body condition score, fecal soiling, overgrown claws, abscess, udder asymmetry, ocular discharge and nasal discharge. Overgrown claws indicator was adapted to assess all hooves. The authors preferred this approach as this is a problem frequently observed in milk goats that interferes with milk production and is a critical problem of animal welfare (Battini et al., 2014).

All indicators were evaluated by the same person even at second level welfare assessment that should be done by two people according to AWIN Goat protocol (Mattiello et al., 2015). The authors opted for this choice due to the difficulty of finding trained assistants to apply the protocol on the farms. Therefore, only one person carried out the evaluations as a way to standardize all the results, even if this required more time per farm. The first author (LOL) is a veterinarian who has one year of experience with goat management. She had a practical training session with the AWIN Goat protocol at the Experimental Farm of Federal University of Paraná, with three hours of duration. 
Table 4. Description of animal-based indicators applied on second level welfare assessment of farms in Ceará, Brazil

\begin{tabular}{ll}
\hline \multicolumn{1}{c}{ Indicator } & \multicolumn{1}{c}{ Description } \\
\hline $\begin{array}{l}\text { Body scoring condition } \\
\text { (BCS) }\end{array}$ & BCS is assessed on individual goats, using a three-level visual scoring method. \\
Abscess & $\begin{array}{l}\text { The presence of external abscesses in front and rear area is recorded. } \\
\text { The presence of soft and liquid manure below the tail head is visually assessed as } \\
\text { a sign of diarrhea. }\end{array}$ \\
Fecal soiling & $\begin{array}{l}\text { The presence of any mucus or purulent discharge from the nose is visually } \\
\text { assessed. }\end{array}$ \\
Tasal discharge & $\begin{array}{l}\text { The presence of clearly visible flow from one or two eyes is visually assessed. } \\
\text { The presence of rear claws that are deformed and/or with excess horn tissue is } \\
\text { visually assessed. }\end{array}$ \\
Ocular discharge & $\begin{array}{l}\text { The presence of asymmetric udders (in which one half is at least 25\% longer than } \\
\text { the other, excluding the teats) is visually assessed. }\end{array}$ \\
Udder asymmetry & ablaws
\end{tabular}

The assessment started at the feed distribution, outside the pens, and continued inside. Temperature $\left({ }^{\circ} \mathrm{C}\right)$ and relative humidity of air $(\%)$ were calculated with a Digital Thermo Hygrometer ITHT2210 at the beginning of the evaluations on each farm. All farms were assessed a single time between August and September 2016. Data were analyzed using IBM SPSS statistics v.19. Indicators related to animal and resources were processed comparing $\mathrm{L}$ and NL. Data were tested for normality with the ShapiroWilk test. Parametric data were analyzed with student's t-test. Nonparametric data were analyzed using chi-square and Fisher's exact test and Mann-
Whitney test for ordinal variables such as BCS. Significance was set at $\mathrm{P}<0.05$. This study was approved by the Animal Use Ethics Committee of the Agricultural Sciences Campus of the Federal University of Paraná, Brazil, protocol number 029/2016.

\section{RESULTS AND DISCUSSION}

There were 56 goats (L) on farms evaluated at pen level and 38 goats (NL) on five farms assessed at pen level. The AWIN assessment began on each farm by measuring mean values for temperature $\left({ }^{\circ} \mathrm{C}\right)$ and relative humidity $(\%)$ (Table 5).

Table 5. Mean values of ambient variables measured in lactating (L) and non-lactating (NL) goats in the morning $(n=5)$ and afternoon $(n=5)$ periods

\begin{tabular}{lcccc}
\multicolumn{1}{c}{ Ambient variables } & & \multicolumn{4}{c}{ L and NL farms } \\
& Morning & min-Max & Afternoon & $\min -$ Max \\
\hline Temperature $\left({ }^{\circ} \mathrm{C}\right)$ & $30,92^{\mathrm{a}}$ & $28,48-36,62$ & $33,59^{\mathrm{a}}$ & $27,67-39,64$ \\
Relative humidity $(\%)$ & $62,90^{\mathrm{a}}$ & $33,95-78,28$ & $46,73^{\mathrm{a}}$ & $33,23-67,36$ \\
\hline
\end{tabular}

Mean values fallowed by different letters in the row have $\mathrm{P}<0.05$.

Animal-based indicators were demonstrated in Table 6. L and NL on farms showed significant difference for queuing at feeding $(\mathrm{P}=0.027)$, in which this behavior was observed 24 times in five $\mathrm{L}$ farms and twice in two NL farms, but not for queuing at drinking $(\mathrm{P}=1.00)$, at first level welfare assessment first welfare level. No goat exhibited either of these two behaviors at second level welfare assessment.

Although there was no difference between the two groups of goats, the occurrence of some indicators shows the need for better animal care. In the first and second level welfare assessments, welfare levels, lactating goats (L) showed signs of thermal stress as panting as a likely attempt to maintenance of homeothermia probably due to higher physiological demands (Speakman, 2008). However, if this behavior is performed for a longer period it may interfere with food intake and rumination (Vieira et al., 2016), causing weight loss and reduced milk yield in dairy goats (Brasil et al., 2000). Thermal stress in these animals occurs when goats are submitted to temperatures above thermal comfort zone $\left(20-30^{\circ} \mathrm{C}\right)$ or critical zone $\left(>34^{\circ} \mathrm{C}\right.$ ) (Baêta and Souza, 2010) and to relative humidity below $40 \%$ or above $80 \%$ in tropical climates (Farm, 1998). 
Table 6. Prevalence of animal-based indicators on goats at first level welfare assessment on five farms with lactating $(\mathrm{L})(\mathrm{n}=56)$ and five with non-lactating $(\mathrm{NL})(\mathrm{n}=38)$ goats at pen and at second level welfare assessment on two farms with lactating $(\mathrm{L})(\mathrm{n}=11)$ and three with non-lactating $(\mathrm{NL})(\mathrm{n}=8)$ goats at pen in Ceará, Brazil

\begin{tabular}{|c|c|c|c|c|c|}
\hline \multirow{2}{*}{$\begin{array}{l}\text { Animal-based } \\
\text { indicators }\end{array}$} & \multicolumn{2}{|c|}{ Number $(\%)$} & \multicolumn{2}{|c|}{ Number (\%) } & \multirow{2}{*}{ p-valor } \\
\hline & Goats & Farms with $\mathrm{L}$ & Goats & Farms with NL & \\
\hline \multicolumn{6}{|c|}{ First level welfare assessment (Pen 1) } \\
\hline Improper disbudding & $1(1.78)$ & $1(20)$ & $3(7.89)$ & $2(40)$ & 1.000 \\
\hline Abscess & $0(0.0)$ & $0(0.0)$ & $0(0.0)$ & $0(0.0)$ & - \\
\hline $\begin{array}{l}\text { Kneeling at the feed } \\
\text { rack }\end{array}$ & $0(0.0)$ & $0(0.0)$ & $0(0.0)$ & $0(0.0)$ & - \\
\hline Hair coat condition & $12(21.42)$ & $4(80)$ & $3(7.89)$ & $1(20)$ & 0.286 \\
\hline Oblivion & $1(1.78)$ & $1(20)$ & $0(0.0)$ & $0(0.0)$ & 1.000 \\
\hline Thermal stress & $3(5.35)$ & $2(40)$ & $0(0.0)$ & $0(0.0)$ & 0.444 \\
\hline Severe Lameness & $0(0.0)$ & $0(0.0)$ & $0(0.0)$ & $0(0.0)$ & - \\
\hline \multicolumn{6}{|c|}{ Second level welfare assessment (Pen 2) } \\
\hline Improper disbudding & $1(9.09)$ & $1(50)$ & $0(0.0)$ & $0(0.0)$ & 0.400 \\
\hline $\begin{array}{l}\text { Kneeling at the feed } \\
\text { rack }\end{array}$ & $0(0.0)$ & $0(0.0)$ & $0(0.0)$ & $0(0.0)$ & - \\
\hline Hair coat condition & $4(36.36)$ & $2(100)$ & $3(37.5)$ & $1(33.33)$ & 0.600 \\
\hline Oblivion & $0(0.0)$ & $0(0.0)$ & $0(0.0)$ & $0(0.0)$ & - \\
\hline Thermal stress & $1(9.09)$ & $1(50)$ & $0(0.0)$ & $0(0.0)$ & 0.400 \\
\hline Severe Lameness & $0(0.0)$ & $0(0.0)$ & $0(0.0)$ & $0(0.0)$ & - \\
\hline
\end{tabular}

$* \mathrm{P}<0.05$

Although temperature was higher than thermal comfort zone in the majority of farms $(n=9)$, mostly goats showed to be adapted to this condition in Ceará-BR, without showing thermal stress signs. Goats that exhibited heat stress were half breed Saanen/British Alpine or Saanen, an exotic breed widespread in Brazil originated from a cold climate country (Chapaval et al., 2011). Nutritional management, physical modifications of the environment, as sprinkling with natural or forced air movement, and investments in thermoresistant breeds can be some solutions to be applied especially in regions with high temperatures as Brazilian Northeast (Das et al., 2016).

Presence of goats with scurs due to improper disbudding can cause pain related to sequelae as sinusitis (Smith and Sherman, 2009). Besides, goats horned or partially horned had advantage in social dominance and can be more aggressive than hornless ones, especially in feeding through, being important to house both separately (Barroso et al., 2000; Miranda-de-la Lama and Matiello, 2010). The existence of goats with poor hair condition, in first and second level welfare assessment, level, possible occurred due to mineral imbalance, as vitamin $\mathrm{A}$, or diseases as coccidiosis (Smith and Sherman, 2009). It is essential to identify the causes and treat the animals.

Poor hair coat condition indicates an animal's difficulty in maintaining a balanced nutritional and health status (Battini et al., 2014). Goats with rough hair coat showed mineral deficiencies such as magnesium (associated with anorexia), calcium and iron (associated with loss of appetite) and increased sodium and potassium (associated with insufficient food absorption) when compared to animals with normal coat (Battini et al., 2015b). In addition, in this study goats with rough hair coat were also thinner and had a higher prevalence of abnormal lung sounds as a possible result of chronic respiratory problems. Therefore, the prevalence of animals with hair coat condition in first and second level welfare assessments indicates that further investigation on the nutritional and health status of these goats are necessary.

Queuing at feeding is influenced by number of animals per feeding through, quality of feeding and social dominance, in which low rank goats suffer more than medium and high rank animals, including with aggressive interactions (Jorgensen et al., 2007). This behavior occurred 24 times in $\mathrm{L}$ (Farms 1 to 4), possibly due to the high 
metabolic demand of lactation, and 4 times in NL (Farms 1 and 4). It was also observed in small (26\%), medium $(12.6 \%)$ and large $(29.8 \%)$ dairy goat farms in Portugal (Can et al., 2016), considered an important welfare problem of these animals in this country. Brazilian manuals recommended 20-30 cm per goat at feeding through (Manejo, 2009; Sandoval Jr, 2011) while Toussaint (1997) cited that $40 \mathrm{~cm}$ per through is the minimum recommended for goats. In pen with $\mathrm{L}$, the smallest space was $41 \mathrm{~cm}$ (Table 7) demonstrating that it was not enough to prevent the formation of queuing at feeding. Loretz et al. (2004) showed that more space should be provided for horned goats.

The occurrence of queuing at drinking in pen with NL (Farm 5) demonstrates the need to increase the length $(0.12 \mathrm{~m})$ of linear water trough per goat (Table 7). Goats are gregarious animals and only isolate themselves from inherit in moments before delivery (Lickliter, 1985), or due to health problems, standing immobile and facing parts of the housing structure (Battini et al., 2014). Although only one goat has shown this behavior in the present study, constant herd monitoring should be carried out to determine which animals are presenting isolation and to detect welfare problems related to this indicator, as health issues (Battini et al., 2014).

The absence of incidence of other animal-based indicators suggests adequate health management. Non-lactating goats in both welfare level had a better result than lactating goats probably due to the high metabolic demands of lactation that needs to be compensated with a better management to prevent farm animals to get sick. There was no significant difference $(\mathrm{P}<0.05)$ between the two groups of farms regarding resource-based indicators (Table 7 and Table 8).

Table 7. Prevalence of resource-based indicators on lactating (L) and non-lactating (NL) goats in farms in the first and second level welfare assessments in Ceará, Brazil

\begin{tabular}{|c|c|c|c|c|c|c|}
\hline $\begin{array}{c}\text { Farm } \\
\text { Goat status }\end{array}$ & $\begin{array}{l}\text { Stocking } \\
\text { density }\end{array}$ & $\begin{array}{l}\text { Number of } \\
\text { feeding } \\
\text { spaces }\end{array}$ & $\begin{array}{l}\text { The length } \\
\text { (m) of } \\
\text { feeding } \\
\text { trough(s) per } \\
\text { goats }\end{array}$ & $\begin{array}{l}\text { Number of } \\
\text { functioning } \\
\text { water places }\end{array}$ & $\begin{array}{l}\text { Total length } \\
(\mathrm{m}) \text { of linear } \\
\text { water } \\
\text { trough(s) per } \\
\text { goat } \\
\end{array}$ & $\begin{array}{c}\text { Presence of } \\
\text { horned and } \\
\text { dehorned } \\
\text { goats } \\
\text { (Yes/No) } \\
\end{array}$ \\
\hline & \multicolumn{6}{|c|}{ First level welfare assessment (Pen 1) } \\
\hline Farm 1 L & 2.27 & 1 & 1.07 & 1 & $\mathrm{Na}$ & Yes \\
\hline Farm 2 L & 2.56 & 1 & 0.42 & 1 & $\mathrm{Na}$ & No \\
\hline Farm $3 \mathrm{~L}$ & 7.15 & 2 & 0.41 & 1 & $\mathrm{Na}$ & No \\
\hline Farm $4 \mathrm{~L}$ & 4.19 & 2 & 0.74 & 2 & $\mathrm{Na}$ & No \\
\hline Farm $5 \mathrm{~L}$ & 1.57 & 2 & 0.55 & 1 & 0.12 & No \\
\hline Farm $1 \mathrm{NL}$ & 7.47 & 1 & 0.55 & 1 & $\mathrm{Na}$ & Yes \\
\hline Farm $2 \mathrm{NL}$ & 1.22 & 1 & 0.11 & 1 & $\mathrm{Na}$ & Yes \\
\hline Farm $3 \mathrm{NL}$ & 2.47 & 1 & 0.37 & 1 & $\mathrm{Na}$ & No \\
\hline Farm $4 \mathrm{NL}$ & - & 1 & 0.61 & 2 & $\mathrm{Na}$ & No \\
\hline \multirow[t]{2}{*}{ Farm 5 NL } & 0.93 & 2 & 0.29 & 1 & 0.12 & Yes \\
\hline & \multicolumn{6}{|c|}{ Second level welfare assessment (Pen 2) } \\
\hline Farm $2 \mathrm{~L}$ & 2.18 & 1 & 0.57 & 1 & $\mathrm{Na}$ & No \\
\hline Farm $5 \mathrm{~L}$ & 1.57 & 2 & 0.55 & 1 & 0.12 & Yes \\
\hline Farm $1 \mathrm{NL}$ & 14.24 & 1 & 0.55 & 1 & $\mathrm{Na}$ & No \\
\hline Farm $2 \mathrm{NL}$ & 3.9 & 2 & 0.32 & 1 & $\mathrm{Na}$ & Yes \\
\hline Farm $3 \mathrm{NL}$ & 3.2 & 1 & 0.37 & 1 & $\mathrm{Na}$ & No \\
\hline
\end{tabular}

$\mathrm{Na}=$ Not applied. The water trough was not linear and, as recommended by AWIN goat (MATTIELLO et al., 2015), it was not assessed. 
Table 8. Resource-based indicators on lactating (L) and non- lactating (NL) goats on farms in the first and second level welfare assessments in Ceará, Brazil

\begin{tabular}{|c|c|c|c|c|}
\hline $\begin{array}{c}\text { Farm } \\
\text { Goat status }\end{array}$ & $\begin{array}{l}\text { Flooring } \\
\text { Material }\end{array}$ & $\begin{array}{l}\text { Bedding } \\
\text { material }\end{array}$ & $\begin{array}{c}\text { Quantity of bedding } \\
\text { (Insufficient/Sufficient/ } \\
\text { No bedding) }\end{array}$ & $\begin{array}{l}\text { Cleanness of } \\
\text { bedding } \\
\text { (Dirty/ } \\
\text { Clean/No } \\
\text { bedding) }\end{array}$ \\
\hline \multicolumn{5}{|c|}{ First level welfare assessment (Pen 1) } \\
\hline Farm $1 \mathrm{~L}$ & Concrete & Straw & Insufficient & Dirty \\
\hline Farm $2 \mathrm{~L}$ & Concrete & No bedding & No bedding & No bedding \\
\hline Farm $3 \mathrm{~L}$ & Sand & No bedding & No bedding & No bedding \\
\hline Farm $4 \mathrm{~L}$ & Wood slatted floor & No bedding & No bedding & No bedding \\
\hline Farm $5 \mathrm{~L}$ & Wood slatted floor & No bedding & No bedding & No bedding \\
\hline Farm $1 \mathrm{NL}$ & Bare soil & No bedding & No bedding & No bedding \\
\hline Farm 2 NL & Concrete & No bedding & No bedding & No bedding \\
\hline Farm 3 NL & Bare soil/concrete & Sand & Insufficient & Dirty \\
\hline Farm 4 NL & Bare soil & No bedding & No bedding & No bedding \\
\hline Farm 5 NL & Wood slatted floor & No bedding & No bedding & No bedding \\
\hline \multicolumn{5}{|c|}{ Second level welfare assessment (Pen 2) } \\
\hline Farm $2 \mathrm{~L}$ & Concrete & No bedding & No bedding & No bedding \\
\hline Farm $5 \mathrm{~L}$ & Wood slatted floor & No bedding & No bedding & No bedding \\
\hline Farm $1 \mathrm{NL}$ & Bare soil & No bedding & No bedding & No bedding \\
\hline Farm 2 NL & Concrete & No bedding & No bedding & No bedding \\
\hline Farm $3 \mathrm{NL}$ & Bare soil & Sand & Insufficient & Clean \\
\hline
\end{tabular}

Animal welfare is influenced by environment, and the floor area size of the area is an important component in promoting comfort to them. Some authors recommended different sizes of floor area to adult goats without kids, including Brazilian manuals (Manejo, 2009; Sandoval Jr, 2011), ranged from 1.0 to $1.75 \mathrm{~m}^{2}$ (Toussaint, 1997; Loretz et al., 2004), and New Zealand Government (2012) suggested $2 \mathrm{~m}^{2}$ per mature goat. In this sense, the present study showed that at least one pen (Table 7) had poor space per goat. Loretz et al. (2004) cited that goats are more individualistic animals than sheep and prefer larger individual spaces for lying down, without contact with other individuals (Andersen and Boe, 2007). Inadequate spaces promote social stress among the animals, with possible aggressions between goats, with low rank goats being more affected with decrease of resting time (Andersen and Boe, 2007). These last authors also said that when there is a limited area for animals it is important to use different floor levels and provide a wall area aiming to increase the safety feeling.

The length (m) of feeding trough(s) per goats was poor $(<40 \mathrm{~cm})$ in four pens (Table 7$)$. Small trough spaces increase competition for food, and low rank goats need to share feeding places or only access food after high rank animals (Loretz et al., 2004), enhancing the number of animals in queuing (Jorgensen et al., 2007), also observed in this study. In addition, the presence of horned and hornless goats together at two of these farms (Table 7) with poor space at feeding through occurred. Nordmann et al (2011) cited that the design of feeding place impacts on social behavior and the use of a feed barrier is useful. As results, they found out that feed barrier made by metal palisade reduce levels of agonistic behaviors as well as reduction of chronic stress when horned and hornless goats were kept on separate pen.

In lambs and goat kids, water intake increased as the number of animals per pen increased (Van et al., 2007), being important that goats have an adequate space for drinking. Most of the drinkers on the evaluated farms were automatic and therefore were not included in this assessment (Table 7, Na=Not applied) as recommended by AWIN Goat (Mattiello et al., 2015). Among the three pen with total length of linear water trough (s) per goat equal to $0.12 \mathrm{~m}$, only one (Table 7 ) had animals performing queuing at drinking. Most of the drinkers on the evaluated farms were automatic and therefore were not included in this assessment (Table 7, Na=Not applied) as recommended by AWIN Goat (Mattiello et al., 2015). Poor values of stocking density (lowest of 
all pen) and length of feed trough (s) per goats may have contributed to this. Since goats prefers to drink around feeding time (Rossi and Scharrer, 1992), the restriction of this behavior decreases food intake (Langhans et al., 1989).

Bedding quantity was not adequate at first and second level welfare assessments, especially on farms where the floor type was concrete (Table 8). In dairy cows, insufficient bedding is a predisposing factor to high incidence and prevalence of lameness (Faull et al., 1996). An adequate bedding layer, between 7.62 to 10.16 $\mathrm{cm}$, should be provided to ensure comfort for goats (Smith, 2010). Frequency of cleanliness must be performed depending on the area size and number of animals per pen (Sandoval Jr, 2011). It is important that bedding material do not become wet, moldy or noxious to goats to avoid risks for their welfare and health (New Zealand
Governament, 2012) as the development of foot diseases (Christodoulopoulos, 2009). Given that most farms in Ceará do not use bedding, cleanliness of facilities is a resource-based indicator that could be used in welfare assessments in goats in Brazilian Northeast (Leite et al., 2017).

The application of Latency to the first contact test (LFCT) aims to evaluate human-animal relationship (HAR), trying to identify if animals are gently handled AWIN Goat (Mattiello et al., 2015). The assessor stayed inside the pen for at least 300s waiting for goat's interactions. Table 9 shows the results of $\mathrm{L}$ and NL evaluated in the pen. There was no significant difference $(\mathrm{P}<0.05)$ between the two groups of farms related to LFCT at first $(\mathrm{P}=0.167)$ and second $(\mathrm{P}=0.393)$ level welfare assessments.

Table 9. Mean (min-max) values of latency to the first contact (seconds) of lactating (L) and non-lactating (NL) goats at first and second level welfare assessments on farms in Ceará, Brazil

\begin{tabular}{lc} 
& L and NL on farms \\
\hline & First level welfare assessment (Pen 1) \\
L on farms & $203.6(91-300)$ \\
NL on farms & $95.6(14-300)$ \\
& Second level welfare assessment $($ Pen 2$)$ \\
L on farms & $99(46-152)$ \\
NL on farms & $215(45-300)$ \\
\hline
\end{tabular}

Observing the reaction of animals to human presence is a way of assessing the emotions involved in this interaction that are usually based on previous negative, neutral or positive contacts (Waiblinger et al., 2006). After 24 days of gently contact through stroking, goats that received a positive human handling approached the experimenter more quickly ( $\bar{X}=228$ seconds) than the animals that were not gentling $(\bar{X}=419$ seconds) (Jackson and Hackett, 2007). Due to daily contact regarding milking, it was expected that $\mathrm{L}$ had a longer approach time from the evaluator, however these goats could be dealing with negative experiences during milking, as fear of handler (Sevi et al., 2009), or pain sensation due to inflammation in the udder.

Although the goats in the present study had lower averages time in both levels of welfare assessment (Table 9) than the study by Jackson and Hackett (2007), obtaining lower values on LFCT should be encouraged, as the results $(\bar{X}=81.1$ seconds) observed in goats on larger farms $(834 \pm 451)$ in
Portugal (Can et al., 2016). The continuous search for improvements in the relationship between humans and goats should encompass factors as body and udder health (Caroprese et al., 2009), adequate choice of handlers and daily gentle contact (Waiblinger et al., 2006) with lactating and non-lactating goats. In addition, the influence of goat breed, related with docility and ease of handling (Can et al., 2016), and temperament (Lyons et al., 1988) need to be studied to assess the impact on the results of LFCT.

$70 \mathrm{~L}$ and $48 \mathrm{NL}$ were evaluated at individual level. In $\mathrm{L}$, the results of BCS related to score -1 (thin), 0 (adequate) and 1 (fat) were 20 goats $(28.6 \%), 43$ goats $(61.4 \%)$ and 7 goats $(10 \%)$, respectively. In $\mathrm{NL}$, the results of BCS related to score $-1,0$ and 1 were 26 goats $(54.17 \%), 21$ goats $(43.75 \%)$ and one goat $(2.08 \%)$, respectively. There was significant difference between $\mathrm{L}$ and $\mathrm{NL}$ regarding to $\mathrm{BCS}(\mathrm{P}=0.003)$. 
As for the thin score (-1), both L and NL had a high number of goats in this state $(>25 \%)$, with NL in worse condition. This probably occurred due to an inadequate diet, especially regarding roughage due to dry season in Ceará-BR at the time of evaluation (Monitor, 2016). Low BCS may also be related to diseases on herds, as gastrointestinal parasites, as high temperatures,-or the presence of dominant animals that prevent adequate feeding to others (Smith and Sherman, 2009), as was observed mainly on L farms. Although more lactating goats are expected to have a lower score due to the physiological demands of milk production (Speakman, 2008), it is likely that Ceará farmers provided better quality food for lactating animals.
Fat goats $(\mathrm{BCS}=1)$ were present at this study, but less than other categories in both groups $(<11 \%)$, and it is important to identify these individuals aiming to provide a good BCS, considering that animals with very high BCS are predisposed to have reproductive problems, as dystocia (Smith and Sherman, 2009). Over $40 \%$ of L and NL in this study had adequate score $(\mathrm{BCS}=0)$. In order to transform the Northeastern goat farming into a more competitive sector in Brazil, based on practices that aim animal welfare, a better nutritional management of goats should be performed. The prevalence of animal-based parameters at individual level are showed on Table 10.

Table 10. Prevalence of animal-based indicators on lactating (L) (n=70) and non-lactating (NL) goats $(\mathrm{n}=48)$ on farms at individual level in Ceará, Brazil

\begin{tabular}{lclllc}
\multicolumn{1}{c}{\begin{tabular}{c} 
Animal-based \\
\multicolumn{1}{c}{ indicators }
\end{tabular}} & \multicolumn{2}{c}{ Number $(\%)$} & \multicolumn{2}{c}{ Number $(\%)$} & NL \\
\hline Fecal soiling & $0(0.00)$ & $0(00.0)$ & $0(0.00)$ & $0(00.0)$ & - \\
Overgrown claws & $17(24.3)$ & $4(80)$ & $1(2.1)$ & $1(20)$ & $0.001^{*}$ \\
Abscess & $1(1.4)$ & $1(20)$ & $0(0.00)$ & $0(00.0)$ & 1.000 \\
Udder asymmetry & $12(17.1)$ & $6(60.0)$ & $0(0.00)$ & $0(00.0)$ & $0.001^{*}$ \\
Ocular discharge & $7(10)$ & $2(40.0)$ & $3(6.3)$ & $2(40)$ & 0.738 \\
Nasal discharge & $2(2.9)$ & $2(40.0)$ & $0(0.0)$ & $0(0.00)$ & 0.513 \\
\hline
\end{tabular}

${ }^{*} \mathrm{P}<0.05$

Soft fecal material was not identified in our study. At the time of assessments on the farms, there was a severe drought in Ceará-BR in AugustSeptember 2016 (Monitor, 2016) and it is possible that animals were not infected with gastrointestinal parasites due to correct sanitary management on farms or because larvae were in a non-infectious stage, with absence of clinical signs of parasitism (Costa et al., 2011). Overgrown claws are a major predisposing factor of lameness in goats (Eze, 2002; Christodoulopoulos, 2009). According to Pinheiro et al., (2000), hoof trimming was performed only in $16.5 \%$ of the farms in CearáBR, usually twice a year (81\%). In Maranhão, Northeast, Brazil this practice was observed in $35.4 \%$ of the farms and similarly in goats on the farms of Maranhão (Teixeira et al., 2015).

The occurrence of overgrowth claw was $79.8 \%$ in goats in 24 dairy goat farms in Italy, with animals affected at all evaluated sites (Anzuino et al., 2010). In Portugal, goats with occurrence of overgrowth claw were observed on small
$(11.4 \%)$, medium $(37.5 \%)$ and large $(45.8 \%)$ farms (Can et al., 2016). This inadequate management of animals is a possible cause of diseases such as foot rot. In Ceará, foot rot was found on $67.7 \%$ farms (Pinheiro et al., 2000), and similarly in goats on $70.7 \%$ farms in Maranhão (Teixeira et al., 2015). Lameness suggestive of foot rot was detected in sheep and goats in $49.2 \%$ properties in Pernambuco, Northeast, Brazil (Alencar et al., 2010). It was possible that L were less handling than NL, regarding hoof trimming, in order to avoid stress to the animals which could, consequently, reduce milk production. However, Kibar and Çaglayan (2016) concluded that dairy cows had increased milk yield after claw trimming. Evaluate the potential of hoof trimming in predicting the onset of diseases such as foot rot is important. This procedure is still neglected on goats on farms of different sizes as well as in different countries and deserves more attention.

Low incidence of abscesses in $\mathrm{L}$ and zero in NL demonstrated an adequate sanitary management, with animals possible being protect from Caseous 
Lymphadenitis (CL) (Smith and Sherman, 2009). Annual vaccination against $\mathrm{CL}$ is an important measure to insure health and welfare for goats (Windsor and Bush, 2016). Udder asymmetry was prevalent only in lactating animals. The results of this study were similar to those observed in dairy goats in Italy, where there was a prevalence of moderate $(15.8 \%)$ and severe $(6.2 \%)$ asymmetry of udder (Anzuino et al., 2010). This indicator has been associated with chronic intramammary infection, as CAE, mastitis and contagious agalactiae, with consequently atrophy of one half of udder (Battini et al., 2014). Improving hygiene during milking and performing vaccination associated with antibiotic therapy are important strategies to prevent mastitis in small ruminants (Peixoto et al., 2010).

Presence of ocular discharge (Table 10) in dry season could be due to ration dust (Chapaval et al., 2011) or diseases (Smith and Sherman, 2009) as keratoconjunctivitis an important disorder affecting goats on farms in Ceará-BR $(29.1 \%)$ (Pinheiro et al., 2000). Nasal discharge (Table 10) has several causes as nutritional, parasitic, infectious and non-infectious diseases (Smith and Sherman. 2009). Low incidence of this condition could be due to dry season, since pneumonia was reported on $44.9 \%$ of the farms in Ceará-BR during rainy season (Pinheiro et al., 2000), which was not the case in our study.

Application of a modified AWIN Goat protocol (Mattiello et al., 2015) on farms in Ceará, Northeast, Brazil was considered positive, with all indicators used in this study easy and practical to apply. However, it is interesting that the evaluation of farms should be carried out in both dry and rainy periods, considering the environmental changes that occur in the last one as the increase in humidity, which favor the incidence of diseases such as gastrointestinal parasites.

\section{CONCLUSION}

These results demonstrated that both groups were submitted to welfare problems on farms in Ceará, Northeast, Brazil. At pen evaluations in the first and second level welfare assessments, there were differences in evaluations between lactating and non-lactating goats regarding queuing at feeding. Health problems and poor housing were observed in lactating and non-lactating goats. Better results regarding the relationship between humans and goats should be encouraged in both groups. During individual assessments, in second level welfare assessment, non-lactating goats had worst conditions regarding $\mathrm{BCS}$, with a larger amount of very thin animals in the evaluations. However, there were more lactating goats with overgrown claws and udder asymmetry. Although lactating goats had higher metabolic demands when comparing with non-lactating, this study showed great similarities between $\mathrm{L}$ and NL regarding almost all indicators. These results demonstrated that both groups were submitted to welfare problems in farms in Ceará, Northeast, Brazil. The modified AWIN Goat protocol used in this study may help the identification of welfare problems in goats, being important that future studies also focus on the feasibility of welfare of non-lactating adult goats. Although the AWIN Goat protocol was developed to evaluate the welfare of adult lactating goats, it can also be used to evaluate nonlactating adult goats, being this procedure recommended by the authors aiming that all animals have a good quality of life and improved welfare.

\section{REFERENCES}

ALENCAR, S.P.; MOTA, R.A.; COELHO, M.C.O.C. et al. Perfil sanitário dos rebanhos caprinos e ovinos no Sertão de Pernambuco. Ciênc. Anim. Bras., v.11, p.131140,2010

ANDERSEN, I.L.; BOE, K.E. Resting pattern and social interactions in goats-the impact of size and organisation of lying space. Appl. Anim. Behav. Sci., v.108, p.89-103, 2007.

ANZUINO, K.; BELL, N.J.; BAZELEY, K.J.; NICOL, C.J. Papers assessment of welfare on 24 commercial UK dairy goat farms based on direct observations. Vet. Rec., v.167, p.774-780, 2010.

BAÊTA, F.C.; SOUZA, C.F. Ambiência em edificações rurais: conforto animal. Viçosa: UFV, 2010. 269p.

BARROSO, F.G.; ALADOS, C.L.; BOZA, J. Social hierarchy in the domestic goat: effect on food habits and production. Appl. Anim. Behav. Sci., v.69, p.35-53, 2000.

BATTINI, M.; STILWELL, G.; VIEIRA, A. et al. Onfarm welfare assessment protocol for adult dairy goats in intensive production systems. Animals, v.5, p.934950, 2015a. 
BATTINI, M.; TANJA, P.; AJUDA, I. et al. Hair coat condition: a valid and reliable indicator for on-farm welfare assessment in adult dairy goats. Small Ruminant Res., v.123, p.197-203, 2015b.

BATTINI, M.; VIEIRA, A.; BARBIERI, S. et al. Invited review: animal-based indicators for on-farm welfare assessment for dairy goats. J. Dairy Sci., v.97, p.1-24, 2014.

BAXTER, E.M.; MULLIGAN, J.; HALL, S. A. et al. Positive and negative gestational handling influences placental traits andmother-offspring behavior in dairy goats. Physiol. Behav., v.157, p.129-138, 2016.

BRASIL, L.H.D.A., WECHESLER, F.S., JÚNIOR, F. B. et al. A. Efeitos do Estresse Térmico Sobre a Produção, Composição Química do Leite e Respostas Termorreguladoras de Cabras da Raça Alpina. Rev. Bras. Zootec., v.29, p.1632-1641, 2000.

BRIEFER, E.F.; TETTAMANTI, F.M.; CELLIGOTT, A.G. Emotions in goats: mapping physiological, behavioural and vocal profiles. Anim. Behav., v.99, p.131-143, 2015.

BROOM, D.M. Indicators of poor welfare. Br. Vet. J., v.142, p.524-526, 1986.

CAN, E.; VIEIRA, A.; BATTINI, M.; MATTIELLO, S.; STILWELL, G. On-farm welfare assessment of dairy goat farms using animal-based indicators: the example of 30 commercial farms in Portugal. Acta Agric. Scand. Sect. A Anim. Sci., v.66, p.43-55, 2016.

CAROPRESE, M.; CASAMASSIMA, D.; RASSU, S.P.G.; NAPOLITANO, F.; SEVI, A. Monitoring the on-farm welfare of sheep and goats. Ital. J. Anim. Sci., v.8, p.343-354, 2009.

CHAPAVAL, L.; OLIVEIRA, A.A.F.; ALVES, F.S.F. et al. Manual do produtor de cabras leiteiras. Viçosa: Aprenda Fácil, 2011. 204p.

CHRISTODOULOPOULOS, G. Foot lameness in dairy goats. Res. Vet. Sci., v.86, p.281-284, 2009.

COSTA, V.M.M.; SIMÕES, S.V.D.; RIET-CORREIA, F. Controle das parasitoses gastrintestinais em ovinos e caprinos na região semiárida do Nordeste do Brasil. Pesqui. Vet. Bras., v.31, p.65-71, 2011.

DAS, R.; SAILO, L.; VERMA, N. et al. Impact of heat stress on health and performance of dairy animals: a review. Vet. World, v.9, p.260-268, 2016.

DWYER, C., RUIZ, R., BELTRAN DE HEREDIA, I. et al. welfare assessment protocol for sheep. 2015. Available on: https://air.unimi.it/handle/2434/ 269114\#.XzMjtyhKjIU. Accessed: 10 dez. 2016.

EZE, C.A. Lameness and reproductive performance in small ruminants in Nsukka area of the Enugu State, Nigeria. Small Ruminant Res., v.44, p.263-267, 2002.
FARM structures in tropical climates. Rome: FAO/INPHO, 1998. Available in: http://www.fao.org/3/s1250e/S1250E10.htm\#Animal $\% 20$ environmental\%20requirements. Accessed in: 22 Feb. 2016.

FAULL, W.B.; HUGHES, J. W.; CLARKSON, M.J. et al. Epidemiology of lameness in dairy cattle: the influence of cubicles and indoor and outdoor walking surfaces. Vet. Rec., v.139, p.130-136, 1996.

FERREIRA, M. I. C., SILVA, M. R., FONSECA, J. F. EMBRAPA: Documentos 199. Anais do $13^{\circ}$ Workshop sobre Produção de Caprinos na Região da Mata Atlântica. 2016. Available in: https://www.alice.cnptia.embrapa.br/alice/bitstream/do c/1051053/1/CNPC2016Doc119.pdf. Assessed: 10 Jan. 2017.

GROSSO, L.; BATTINI, M.; WEMELSFELDER, F. et al. On-farm qualitative behaviour assessment of dairy goats in different housing conditions. Appl. Anim. Behav. Sci., v.180, p.51-57, 2016.

JACKSON, K.M.A.; HACKETT, D. A note: the effects of human handling on heart girth, behaviour and milk quality in dairy goats. Appl. Anim. Behav. Sci., v.108, p.332-336, 2007.

JORGENSEN, G.H.M.; ANDERSEN, I.L.; BOE, K.E. Feed intake and social interactions in dairy goats-the effects of feeding space and type of roughage. Appl. Anim. Behav. Sci., v.107, p.239-251, 2007.

KIBAR, M.; ÇAGLAYAN, T. Effect of hoof trimming onmilk yield in dairy cows with foot disease. Acta Sci. Vet., v.44, p.1-7, 2016.

LANGHANS, W.; SENN, M.; MEYER, A.H.; SCHARRER, E. Feeding behaviour of pigmy goats during water deprivation. Asian Australas. J. Anim. Sci., v.2, p.273-274, 1989.

LEITE, L.O.; STAMM, F.D.O.; GARCIA, R.D.C.M. Indicators to assess goat welfare on-farm in the semiarid region of Brazilian Northeast. Ciênc. Rural, v.47, p.1-8, 2017.

LICKLITER, R.E. Behavior associated with parturition in the domesti goat. Appl. Anim. Behav. Sci., v.13, p.335-345, 1985.

LIMA, L.R.; BARBOSA FILHO, J.A.D. Impact of preslaughter management on the welfare of goats and sheep. J. Anim. Behav. Biometeorol., v.1, p.52-60, 2013.

LORETZ, C.; WECHSLER, B.; HAUSER, R.; RÜSCH, P. A comparison of space requirements of horned and hornless goats at the feed barrier and in the lying area. Appl. Anim. Behav. Sci., v.87, p.275-283, 2004. 
LYONS, D.M.; PRICE, E.O.; MOBERG, G.P. Individual differences in temperament of domestic dairy goats: constancy and change. Anim. Behav., v.36, p.1323-1333, 1988.

MANEJO básico de ovinos e caprinos. Brasília: SEBRAE, 2009. 137p.

MATTIELLO, S., BATTINI, M., VIEIRA, A., STILWELL, G. AWIN welfare assessment protocol for goats. 2015. Available on: https://air.unimi.it/handle/2434/269102\#.XzMi8ChKjI U. Acessed: 10 dez. 2016.

MERSMANN, D.; SCHMIED-WAGNER, C.; NORDMANN, E.; GRAML, C.; SUSANNE, W. Influences on the avoidance and approach behaviour of dairy goats towards an unfamiliar human-An on-farm study. Appl. Anim. Behav. Sci., v.179, p.60-73, 2016.

MIRANDA-DE LA LAMA, G.C.; MATTIELLO, S. The importance of social behaviour for goat welfare in livestock farming. Small Ruminant Res., v.90, p.1-10, 2010.

MONITOR das secas do Nordeste brasileiro. [Fortaleza]: ANA, 2016. Available on: http://monitordesecas.ana.gov.br/. Accessed: 23 fev. 2017.

NEW Zealand Government. Animal welfare (goats) code of welfare. 2012.

NORDMANN, E.; KEIL, N.M.; SCHMIEDWAGNER, C. et al. Feed barrier design affects behaviour and physiology in goats. Appl. Anim. Behav. Sci., v.133, p.40-53, 2011.

PAULO, J.L.A.; LOPES, F.A. Daily activity patterns of Saanen goats in the semi-arid northeast of Brazil. Rev. Bras. Zootec., v.43, p.464-470, 2014.

PEIXOTO, R.D.M.; MOTA, R.A.; COSTA, M.M. Mastite em pequenos ruminantes no Brasil. Pesqui. Vet. Bras., v.30, p.754-762, 2010.

PINHEIRO, R.R.; GOUVEIA, A.M.G.; ALVES, F.S.F.; HADDAD, J.P.A. Aspectos epidemiológicos da caprinocultura cearense. Arq. Bras. Med. Vet. Zootec., v.52, p.534-543, 2000.

PPM. Produção da pecuária municipal. Rio de Janeiro: IBGE, 2016.QUEIROZ, M. L.D.V.; BARBOSA FILHO, J.A.D.; ALBIERO, D.; BRASIL, D.D.F.; MELO, R.P. Percepção dos consumidores sobre o bemestar dos animais de produção em Fortaleza, Ceará. Rev. Ciênc. Agron., v.45, p.379-386, 2014.
ROSSI, R.; SCHARRER, E. Circadian patterns of drinking and eating in pygmy goats. Physiol. Behav., v.51, p.895-897, 1992.

SALEM, H.B. Nutritional management to improve sheep and goat performances in semiarid regions. Rev. Bras. Zootec., v.39, p.337-347, 2010.

SANDOVAL Jr. P. (Cood.). Manual de criação de caprinos e ovinos. Brasília: Codevasf, 2011. 142p.

SEVI, A.; CASAMASSIMA, D.; PULINA, G.; PAZZONA, A. Factors of welfare reduction in dairy sheep and goats. Ital. J. Anim. Sci., v.8, p.81-101, 2009.

Sistemas de produção de caprinos leiteiros. Brasília: Embrapa. 2016. 13p.

SMITH M. C.; SHERMAN, D.M. Goat medicine. 2.ed. Iowa: Wiley-Blackwell, 2009. 871p.

SMITH, C.K. Raising goats for dummies. Hoboken: Wiley Publishing, 2010. 340p.

SPEAKMAN, J.R. The physiological costs of reproduction in small mammals. Philos. Trans. R. Soc. $B$, v.363, p.375-398, 2008.

TEIXEIRA, W.C.; SANTOS, H.P.; SILVA, J.C.R. et al. Perfil zoosanitário dos rebanhos de caprinos e ovinos em três mesorregiões do estado do Maranhão, Brasil. Acta Vet. Bras., v.9, p.34-42, 2015.

TOUSSAINT, G. The housing ofmilk goats. Livest. Prod. Sci., v.49, p.151-164, 1997.

VAN, D.T.T.; MUI, N.T.; LEDIN, I. Effect of group size on feed intake, aggressive behaviour and growth rate in goat kids and lambs. Small Ruminant Res., v.72, p.187-196, 2007.

VIEIRA, M.M.M.; FURTADO, F.M.V.; CÂNDIDO, M.J.D. et al. Aspectos fisiológicos e bioclimáticos de caprinos nas regiões semiáridas. PubVet, v.10, p.356$369,2016$.

WAIBLINGER, S.; BOIVIN, X.; PEDERSEN, V. et al. Assessing the human-animal relationship in farmed species: a critical review. Appl. Anim. Behav. Sci., v.101, p.185-242, 2006.

WINDSOR, P.A.; BUSH, R.D. Caseous lymphadenitis: Present and near forgotten from persistent vaccination? Small Ruminant Res., v.142, p.6-10, 2016. 